\title{
Post-traumatic stress disorder and cardiometabolic disease: improving causal inference to inform practice
}

\author{
K. C. Koenen ${ }^{1,2 *}$, J. A. Sumner ${ }^{1,3}$, P. Gilsanz ${ }^{4}$, M. M. Glymour ${ }^{4,5}$, A. Ratanatharathorn ${ }^{1,6}$, E. B. Rimm ${ }^{7}$, \\ A. L. Roberts ${ }^{4}$, A. Winning ${ }^{4}$ and L. D. Kubzansky ${ }^{4}$ \\ ${ }^{1}$ Department of Epidemiology, Harvard T.H. Chan School of Public Health, Boston, MA, USA \\ ${ }^{2}$ Psychiatric and Neurodevelopmental Genetics Unit and Department of Psychiatry, Massachusetts General Hospital, Boston, MA, USA \\ ${ }^{3}$ Center for Behavioral Cardiovascular Health, Columbia University Medical Center, New York, NY, USA \\ ${ }^{4}$ Department of Social and Behavioral Sciences, Harvard T.H. Chan School of Public Health, Boston, MA, USA \\ ${ }^{5}$ Department of Epidemiology and Biostatistics, University of California, San Francisco, San Francisco, CA, USA \\ ${ }^{6}$ Department of Epidemiology, Columbia University Mailman School of Public Health, New York, NY, USA \\ ${ }^{7}$ Channing Division of Network Medicine, Brigham and Women's Hospital, Harvard Medical School and Departments of Epidemiology and \\ Nutrition, Harvard T.H. Chan School of Public Health, Boston, MA, USA
}

\begin{abstract}
Post-traumatic stress disorder (PTSD) has been declared 'a life sentence' based on evidence that the disorder leads to a host of physical health problems. Some of the strongest empirical research - in terms of methodology and findings - has shown that PTSD predicts higher risk of cardiometabolic diseases, specifically cardiovascular disease (CVD) and type 2 diabetes (T2D). Despite mounting evidence, PTSD is not currently acknowledged as a risk factor by cardiovascular or endocrinological medicine. This view is unlikely to change absent compelling evidence that PTSD causally contributes to cardiometabolic disease. This review suggests that with developments in methods for epidemiological research and the rapidly expanding knowledge of the behavioral and biological effects of PTSD the field is poised to provide more definitive answers to questions of causality. First, we discuss methods to improve causal inference using the observational data most often used in studies of PTSD and health, with particular reference to issues of temporality and confounding. Second, we consider recent work linking PTSD with specific behaviors and biological processes, and evaluate whether these may plausibly serve as mechanisms by which PTSD leads to cardiometabolic disease. Third, we evaluate how looking more comprehensively into the PTSD phenotype provides insight into whether specific aspects of PTSD phenomenology are particularly relevant to cardiometabolic disease. Finally, we discuss new areas of research that are feasible and could enhance understanding of the PTSD-cardiometabolic relationship, such as testing whether treatment of PTSD can halt or even reverse the cardiometabolic risk factors causally related to CVD and T2D.
\end{abstract}

Received 12 May 2016; Revised 9 August 2016; Accepted 11 August 2016; First published online 4 October 2016

Key words: Cardiovascular disease, causality, diabetes, post-traumatic stress disorder.

\section{Introduction}

Post-traumatic stress disorder (PTSD) is a pervasive and debilitating mental disorder in the USA with a lifetime prevalence of about 7\% (Kessler et al. 2005). PTSD has been declared 'a life sentence' (Abrams \& Manstead, 1981) based on evidence that the disorder leads to a host of physical health problems. While investigators have examined PTSD in relation to a range of health outcomes (including rheumatoid arthritis, stroke, heart disease and cancer), some of the strongest empirical research - in terms of methodology and findings - has been with cardiometabolic diseases

* Address for correspondence: K. C. Koenen, Department of Epidemiology, Harvard T.H. Chan School of Public Health, 677 Huntington Avenue, Kresge 505, Boston, MA 02115, USA.

(Email: kkoenen@hsph.harvard.edu)
(Lohr et al. 2015). Numerous methodologically rigorous prospective population-based observational studies have found that PTSD is associated with increased risk of incident cardiovascular disease (CVD) (Boscarino \& Chang, 1999; Boscarino, 2006, 2008; Kubzansky et al. 2007, 2009; Scherrer et al. 2010; Jordan et al. 2011; Vaccarino et al. 2013; Chen et al. 2015; Gradus et al. 2015; Roy et al. 2015; Sumner et al. 2015; Beristianos et al. 2016) and type 2 diabetes (T2D) (Boyko et al. 2010; Vaccarino et al. 2014; Roberts et al. 2015), even after adjusting for depression (see Table 1).

Despite mounting evidence, PTSD is not acknowledged as a risk factor for either CVD or T2D. For example, neither PTSD nor stress is ranked in the American Heart Association 2010 Impact Goals as a risk factor that requires attention (Lloyd-Jones et al. 2010). Indeed, the American Heart Association explicitly states: 'stress is not a confirmed risk factor for... 
Table 1. Prospective studies of PTSD and incident cardiovascular disease and type 2 diabetes

\begin{tabular}{|c|c|c|c|c|c|c|c|c|c|}
\hline Study & $n$ & Sample & $\begin{array}{l}\text { PTSD } \\
\text { assessment }\end{array}$ & Clinical outcome & 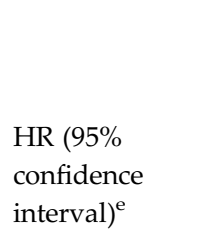 & $\begin{array}{l}\text { HR adjusted for } \\
\text { depression ( } 95 \% \\
\text { confidence } \\
\text { interval); } \\
\text { depression } \\
\text { assessment }\end{array}$ & $\begin{array}{l}\text { Mean age } \\
\text { at } \\
\text { baseline, } \\
\text { years }\end{array}$ & $\begin{array}{l}\text { Mean } \\
\text { follow-up, } \\
\text { years }\end{array}$ & Covariates \\
\hline $\begin{array}{l}\text { Boscarino } \\
(2008)^{\mathrm{a}}\end{array}$ & 4328 & $\begin{array}{l}\text { US } \\
\text { Vietnam-era } \\
\text { veterans }\end{array}$ & $\begin{array}{l}\text { Self-report based } \\
\text { on DSM-III } \\
\text { criteria }\end{array}$ & Heart disease mortality & $2.25(1.02-4.95)$ & $\begin{array}{r}2.06(0.92-4.62) \\
\text { medical record }\end{array}$ & 36.3 & 15 & $\begin{array}{l}\text { War theater status, age, } \\
\text { intelligence, smoking, BMI, } \\
\text { depression history }\end{array}$ \\
\hline $\begin{array}{l}\text { Jordan et al. } \\
(2011)^{\mathrm{a}}\end{array}$ & 39324 & $\begin{array}{l}\text { World Trade } \\
\text { Center } \\
\text { survivors }\end{array}$ & PCL $>44$ & $\begin{array}{l}\text { Self-reported } \\
\text { physician-diagnosed } \\
\text { heart disease }\end{array}$ & $1.64(1.42-1.91)$ & N.A. & 43.9 & 2.9 & $\begin{array}{l}\text { Age, race/ethnicity, } \\
\text { education, marital status, } \\
\text { smoking, hypertension, } \\
\text { diabetes }\end{array}$ \\
\hline $\begin{array}{l}\text { Kubzansky } \\
\text { et al. }(2007)^{\mathrm{a}}\end{array}$ & 1002 & $\begin{array}{l}\text { US Vietnam } \\
\text { War-era } \\
\text { veterans }\end{array}$ & $\begin{array}{l}\text { Mississippi Scale } \\
\text { for Combat- } \\
\text { Related } \\
\text { PTSD (mean }+2 \\
\text { S.D.) }\end{array}$ & $\begin{array}{l}\text { Non-fatal MI and CHD } \\
\text { mortality }\end{array}$ & $1.42(1.03-1.95)$ & $\begin{array}{l}1.30(0.92-1.80) \\
\text { CES-D }\end{array}$ & 63 & 15 & $\begin{array}{l}\text { Age, smoking, systolic and } \\
\text { diastolic blood pressure, } \\
\text { total cholesterol, BMI, } \\
\text { family history of CHD, } \\
\text { education, alcohol }\end{array}$ \\
\hline $\begin{array}{l}\text { Kubzansky } \\
{\text { et al. }(2009)^{\mathrm{a}}}^{\text {a }}\end{array}$ & 1059 & $\begin{array}{l}\text { Baltimore, MD } \\
\text { women }\end{array}$ & $\begin{array}{l}\text { Diagnostic } \\
\text { Interview } \\
\text { Schedule for } \\
\text { DSM-III }\end{array}$ & $\begin{array}{l}\text { Angina, non-fatal MI, } \\
\text { CHD mortality, other } \\
\text { cardiac death }\end{array}$ & $3.28(1.17-8.90)$ & $\begin{array}{l}2.78(1.10-7.59) \\
\text { DIS }\end{array}$ & 44.4 & 13 & $\begin{array}{l}\text { Age, race/ethnicity, } \\
\text { smoking, history of high } \\
\text { blood pressure, history of } \\
\text { diabetes, alcohol use, } \\
\text { education, income }\end{array}$ \\
\hline $\begin{array}{l}\text { Scherrer } \\
\text { et al. }(2010)^{\mathrm{a}}\end{array}$ & 355999 & $\begin{array}{l}\text { US military } \\
\text { veterans }\end{array}$ & $\begin{array}{l}\text { Two out-patient } \\
\text { or one } \\
\text { in-patient } \\
\text { PTSD diagnosis } \\
\text { codes } \\
\text { (ICD-9-CM: } \\
309.81 \text { ) }\end{array}$ & $\begin{array}{l}\text { Incident MI (ICD-9-CM } \\
\text { codes } 410-411)\end{array}$ & $\begin{array}{l}1.39(1.33-1.46) \\
\text { age-adjusted } \\
\text { only }\end{array}$ & $\begin{array}{l}1.16(1.00-1.35) \\
\text { ICD-9 }\end{array}$ & 55.7 & 7 & $\begin{array}{l}\text { Age, sex, race, marital } \\
\text { status, insurance, diabetes, } \\
\text { hypertension, } \\
\text { hyperlipidemia, obesity, } \\
\text { alcohol, nicotine }\end{array}$ \\
\hline $\begin{array}{l}\text { Vaccarino } \\
\text { et al. }(2013)^{\mathrm{a}}\end{array}$ & 562 & $\begin{array}{l}\text { US Vietnam } \\
\text { War-era } \\
\text { veterans } \\
\text { (twin study) }\end{array}$ & $\begin{array}{l}\text { Diagnostic } \\
\text { Interview } \\
\text { Schedule for } \\
\text { DSM-III }\end{array}$ & $\begin{array}{l}\text { Self-reported hospital } \\
\text { admission for heart } \\
\text { disease }\end{array}$ & $2.20(1.2-4.2)$ & $2.19(1.1-4.1)$ & 42.6 & 13 & $\begin{array}{l}\text { Age, education, family } \\
\text { income, alcohol, smoking, } \\
\text { physical activity, } \\
\text { hypertension }\end{array}$ \\
\hline $\begin{array}{l}\text { Gradus et al. } \\
(2015)^{\mathrm{b}}\end{array}$ & 4724 & $\begin{array}{l}\text { Danish } \\
\text { population }\end{array}$ & ICD-10 & $\begin{array}{l}\text { MI } \\
\text { Stroke } \\
\text { Ischemic stroke } \\
\text { Venous } \\
\text { thromboembolism }\end{array}$ & $\begin{array}{l}1.5(1.1-1.9) \\
1.7(1.4-2.1) \\
1.8(1.4-2.4) \\
2.1(1.7-2.7)\end{array}$ & N.A. & 39.3 & 7.9 & None \\
\hline
\end{tabular}




\begin{tabular}{|c|c|c|c|c|c|c|c|c|c|}
\hline $\begin{array}{l}\text { Sumner et al. } \\
\text { (2015) }\end{array}$ & 49928 & US nurses & $\begin{array}{l}\text { Short Screening } \\
\text { Scale for } \\
\text { DSM-IV PTSD }\end{array}$ & MI, stroke & $\begin{array}{l}\text { Trauma/no } \\
\text { symptoms: } \\
1.38(1.09- \\
1.75) \\
\text { Trauma/1-3 } \\
\text { symptoms: } \\
0.90(0.65- \\
1.25) \\
\text { Trauma/4+ } \\
\text { symptoms: } \\
1.30(0.97- \\
1.74)\end{array}$ & $\begin{array}{l}\text { Trauma/no } \\
\text { symptoms: } 1.48 \\
(1.15-1.91) \\
\text { Trauma/1-3 } \\
\text { symptoms: } 1.07 \\
(0.75-1.51) \\
\text { Trauma/4+ } \\
\text { symptoms: } 1.53 \\
(0.90-2.61)\end{array}$ & 35 & 20 & $\begin{array}{l}\text { Age, race/ethnicity, parental } \\
\text { education, maternal/ } \\
\text { paternal history of MI or } \\
\text { stroke, 5-year somatype, } \\
\text { BMI, smoking, alcohol } \\
\text { intake, physical activity, } \\
\text { diet quality, hypertension, } \\
\text { type } 2 \text { diabetes, hormone } \\
\text { therapy, ADM use }\end{array}$ \\
\hline $\begin{array}{l}\text { Beristianos } \\
\text { et al. }(2016)^{\mathrm{c}}\end{array}$ & 138341 & US veterans & ICD-9-CM & $\begin{array}{l}\text { Cerebrovascular disease, } \\
\text { congestive heart failure, } \\
\text { MI, and peripheral } \\
\text { vascular disease }\end{array}$ & $1.50(1.38-1.63)$ & $1.45(1.33-1.58)$ & 67.8 & About 10 & $\begin{array}{l}\text { Age, sex, zip code, } \\
\text { education, income, TBI, } \\
\text { dementia, renal disease, } \\
\text { hypertension, diabetes, } \\
\text { chronic pulmonary } \\
\text { disease, cancer, depression, } \\
\text { bipolar disorder, } \\
\text { generalized anxiety } \\
\text { disorder, panic disorder, } \\
\text { phobic disorder, substance } \\
\text { abuse, alcohol abuse, } \\
\text { tobacco dependence }\end{array}$ \\
\hline $\begin{array}{l}\text { Roy et al. } \\
\text { (2015) }\end{array}$ & 8248 & US veterans & ICD-9 & Heart failure & N.A. & $1.47(1.13-1.92)$ & 63.8 & 7.2 & $\begin{array}{l}\text { Age, BMI, diabetes, } \\
\text { hyperlipidemia, } \\
\text { hypertension, depression, } \\
\text { anxiety, tobacco use, } \\
\text { substance use disorder, } \\
\text { marital status, combat } \\
\text { service, period of military } \\
\text { service }\end{array}$ \\
\hline $\begin{array}{l}\text { Chen et al. } \\
\text { (2015) }\end{array}$ & 26085 & $\begin{array}{l}\text { Taiwanese } \\
\text { population }\end{array}$ & ICD-9 & $\begin{array}{l}\text { Ischemic and } \\
\text { hemorrhagic stroke }\end{array}$ & $3.37(2.44-4.67)$ & N.A. & 36.7 & 7 & $\begin{array}{l}\text { Age, gender, level of } \\
\text { urbanization, } \\
\text { income-related insured } \\
\text { amount }\end{array}$ \\
\hline $\begin{array}{l}\text { Vaccarino } \\
\text { et al. (2014) }\end{array}$ & 4340 & $\begin{array}{l}\text { US Vietnam } \\
\text { War-era } \\
\text { veterans }\end{array}$ & DSM-III-R & Type 2 diabetes & $1.09(0.81-1.45)$ & $1.18(0.91-1.62)$ & 36 & 19.4 & $\begin{array}{l}\text { Age, race, ethnicity, marital } \\
\text { status, education, branch of } \\
\text { service, enlistment year, } \\
\text { service in SE Asia, military } \\
\text { rank, cigarette smoking, } \\
\text { alcohol use, physical } \\
\text { activity }\end{array}$ \\
\hline
\end{tabular}




\begin{tabular}{|c|c|c|c|c|c|c|c|c|c|}
\hline Study & $n$ & Sample & $\begin{array}{l}\text { PTSD } \\
\text { assessment }\end{array}$ & Clinical outcome & $\begin{array}{l}\text { HR }(95 \% \\
\text { confidence } \\
\text { interval) }\end{array}$ & $\begin{array}{l}\text { HR adjusted for } \\
\text { depression }(95 \% \\
\text { confidence } \\
\text { interval); } \\
\text { depression } \\
\text { assessment }\end{array}$ & $\begin{array}{l}\text { Mean age } \\
\text { at } \\
\text { baseline, } \\
\text { years }\end{array}$ & $\begin{array}{l}\text { Mean } \\
\text { follow-up, } \\
\text { years }\end{array}$ & Covariates \\
\hline $\begin{array}{l}\text { Boyko et al. } \\
(2010)\end{array}$ & 44754 & $\begin{array}{c}\text { US Service } \\
\text { members }\end{array}$ & DSM-IV & Type 2 diabetes & N.A. & $2.06(1.31-3.26)$ & 36.3 & 3 & $\begin{array}{l}\text { Age, race, ethnicity, BMI, } \\
\text { education, enlistment } \\
\text { status, reserve } v \text {. active } \\
\text { duty, panic disorder, } \\
\text { depression interaction with } \\
\text { gender }\end{array}$ \\
\hline $\begin{array}{l}\text { Roberts et al. } \\
(2015)^{\mathrm{d}}\end{array}$ & 54282 & US nurses & $\begin{array}{l}\text { Short Screening } \\
\text { Scale for } \\
\text { DSM-IV PTSD }\end{array}$ & Type 2 diabetes & $\begin{array}{c}\text { Trauma/no } \\
\text { symptoms: } \\
1.22(1.10- \\
1.35) \\
\text { Trauma/1-3 } \\
\text { symptoms: } \\
1.36(1.20- \\
1.55) \\
\text { Trauma/4-5 } \\
\text { symptoms: } \\
1.41(1.22- \\
1.62) \\
\text { Trauma/6-7 } \\
\text { symptoms: } \\
1.48(1.26- \\
1.73)\end{array}$ & $\begin{array}{l}\text { Trauma/no } \\
\text { symptoms: } 1.20 \\
(1.08-1.33) \\
\text { Trauma/1-3 } \\
\text { symptoms: } 1.30 \\
(1.15-1.48) \\
\text { Trauma/4-5 } \\
\text { symptoms: } 1.30 \\
(1.12-1.50) \\
\text { Trauma/6-7 } \\
\text { symptoms: } 1.33 \\
(1.13-1.56)\end{array}$ & N.A. & 22 & $\begin{array}{l}\text { Race, somatotype at } 5 \text { years, } \\
\text { parental education, } \\
\text { maternal and paternal type } \\
2 \text { diabetes, BMI, smoking, } \\
\text { physical activity, diet, } \\
\text { alcohol intake }\end{array}$ \\
\hline
\end{tabular}

PTSD, Post-traumatic stress disorder; HR, hazard ratio; DSM, Diagnostic and Statistical Manual of Mental Disorders; BMI, body mass index; PCL, PTSD Checklist, N.A., not applicable; S.D., standard deviation; MI, myocardial infarction; CHD, coronary heart disease; CES-D, Center for Epidemiologic Studies Depression Scale; DIS, National Institute of Mental Health Diagnostic Interview Schedule; ICD, International Classification of Diseases; ADM, antidepressant medication; TBI, traumatic brain injury; SE, Southeast.

${ }^{a}$ From Edmondson \& Cohen (2013).

${ }^{b}$ Estimate is a standardized incidence rate.

${ }^{\mathrm{c}}$ The HR not adjusted for depression means no adjustment for depression, dysthymia, bipolar disorder, generalized anxiety disorder, panic disorder or phobic disorder.

${ }^{\mathrm{d}}$ Depression variable was anti-depressant medication not diagnosis of depression.

${ }^{\mathrm{e}}$ Multivariate adjusted HR adjusting for listed covariates except where indicated otherwise. 
(a) Confounding: PTSD and cardiometabolic disease share environmental or genetic risk factors (e.g., trauma exposure, maternal trauma exposure, neighborhood environment)

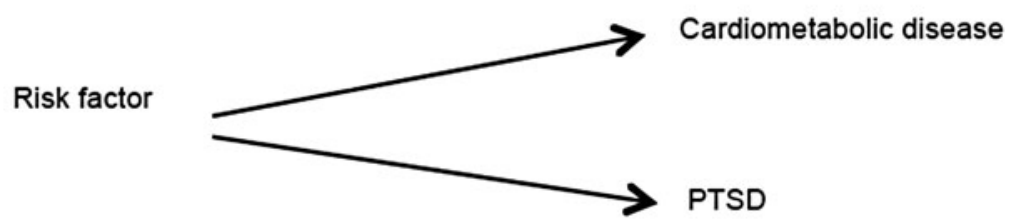

(b) Reverse causation: Cardiometabolic disease causes PTSD

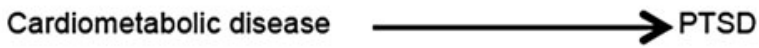

(c) Causation: PTSD causes cardiometabolic disease

PTSD $\longrightarrow$ Cardiometabolic disease

(d) Mediation: PTSD causes smoking, which causes cardiometabolic disease

PTSD $\longrightarrow$ Smoking $\longrightarrow$ Cardiometabolic disease

(e) Bidirectional: PTSD and cardiometabolic disease cause each other

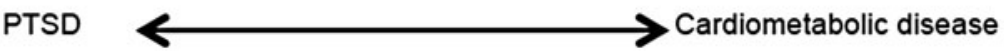

Fig. 1. Possible causal structures of the relationship between post-traumatic stress disorder (PTSD) and cardiometabolic risk.

heart disease, and has not been proven to cause heart disease' (American Heart Association, 2013). In contrast, the American Diabetes Association does cite stress as a potential contributor to poor diabetes management (Godfrey et al. 2013). However, depression is the only mental disorder specifically acknowledged to contribute to diabetes. As a result, neither systematic surveillance nor treatment is provided to individuals with PTSD to reduce potential risk of developing these important diseases. Absent compelling evidence that PTSD causally contributes to CVD and T2D, the approach by cardiovascular and branches of medicine concerned with metabolic diseases, is unlikely to change. At this writing, PTSD has not been established as a causal risk factor for CVD or T2D from the perspective of the larger medical community.

This review offers a roadmap for the next steps needed in research to provide compelling evidence that PTSD causally contributes to cardiometabolic disease. Although we recognize that the term 'cardiometabolic' is broad, we focus on CVD and T2D due to their high importance for population health and strong extant evidence for associations of these diseases with PTSD. We argue that developments in epidemiological methods and the explosion of knowledge about the behavioral and biological effects of PTSD offer new opportunities to provide more definitive answers to questions of causality. First, given that studies of PTSD and physical health rely primarily on observational data, we discuss methods to improve causal inference using such data, with particular reference to the issues of temporality and confounding. Second, we consider recent work (also observational) linking PTSD with specific behaviors and biological processes, and evaluate whether these may plausibly serve as mechanisms by which PTSD leads to cardiometabolic disease. Third, we evaluate how looking more comprehensively into the PTSD phenotype would provide insight into whether specific aspects of PTSD phenomenology are particularly relevant to cardiometabolic disease. Finally, we discuss new areas of research that are feasible and could enhance understanding of the PTSD-cardiometabolic relationship, such as testing whether PTSD treatment alters behaviors and biomarkers on the pathways to CVD and T2D.

Improving causal inference from observational data

There are at least five possible causal structures (Fig. 1) that may explain the well-documented statistical association between PTSD and cardiometabolic disease, 
but only one (scenario c) includes a unidirectional causal impact of PTSD on cardiometabolic disease. Scenario a in Fig. 1 reflects confounding bias, where the relationship between PTSD and cardiometabolic disease is explained by a third variable. Because PTSD is conditional on trauma, the most commonly suggested confounder is trauma exposure. Many types of trauma exposure, from childhood maltreatment (Felitti et al. 1998; Dube et al. 2003; Dong et al. 2004) to combat exposure (Schnurr \& Spiro, 1999; Schnurr et al. 2002), have been linked to chronic disease. Furthermore, predictors of trauma (e.g. neighborhood environment, socio-economic status), which vary by trauma type, may also bias estimates if associated with both PTSD and cardiometabolic risk and left unaccounted for by study designs or analyses. Various other factors have been proposed, including shared genetic vulnerability, lower intelligence quotient, and even maternal trauma and PTSD (Koenen et al. 2007; Schaefer et al. 2015). Moreover, inflammatory biomarkers associated with increased risk of cardiometabolic disease, such as elevated C-reactive protein, have been associated with increased risk of PTSD onset prospectively (Eraly et al. 2014). Thus, inflammation may represent common vulnerability for both PTSD and cardiometabolic disease. However, although C-reactive protein level is considered a useful biomarker of risk for CVD, a large cross-consortium Mendelian randomization analysis did not support a causal role of C-reactive protein in any neuropsychiatric or somatic outcome examined (Prins et al. 2016).

Scenario b in Fig. 1 reflects reverse causation. For example, the accumulation of evidence summarized in meta-analyses indicates that acute life-threatening medical events, like myocardial infarction and stroke, are traumatic events that may trigger PTSD onset (Edmondson et al. 2012; Edmondson \& Cohen, 2013). Epidemiological studies have also shown increased risk of PTSD associated with diagnosis of breast cancer and in critical illness survivors (Vin-Raviv et al. 2013; Parker et al. 2015). It is notable that commonly used assessments for traumatic events such as the Life Events Checklist-V include lifethreatening illness or injury as a potential index trauma for PTSD assessment (Weathers et al. 2013).

Scenario $d$ in Fig. 1 reflects mediation, whereby the effect of PTSD on the outcome is explained by an intermediate variable. We discuss this in more detail in the section below titled 'Elucidating mechanisms to better understand risk'. Finally, scenario e in Fig. 1 reflects a bidirectional relationship between PTSD and cardiometabolic outcomes. A bidirectional association is plausible given evidence for both scenario $b$ (reverse causation) and scenario c (PTSD causes cardiometabolic disease), and is thus a potential focus for future longitudinal research.
Moreover, we see at least two potential forms of bidirectionality. PTSD could lead to increased susceptibility to disease and developing a major disease could be a trauma that leads to PTSD development. Alternatively, PTSD and cardiometabolic disease may mutually influence each other whereby people who have PTSD and then develop a major disease are at greater risk for having more severe PTSD symptoms, which lead to worse disease. To our knowledge, only one longitudinal epidemiological study has examined the first type of bidirectional relationship (El-Gabalawy et al. 2014). This study examined the relationship between anxiety disorders, including PTSD, and physical health conditions (self-reported). The authors did not find evidence for a bidirectional relationship between PTSD and cardiometabolic disease specifically although evidence was suggestive for other physical health outcomes. With regard to the second type of bidirectionality, whereby PTSD influences cardiometabolic disease and vice versa, a recent paper using a convenience sample of veterans employed a cross-lagged analysis to examine a potential bidirectional relationship between PTSD and the metabolic syndrome (Wolf et al. 2016). The authors found evidence that PTSD severity predicted increases in metabolic syndrome severity but metabolic syndrome severity did not predict onset of PTSD. In related work, other longitudinal studies have found evidence of bidirectionality for depression with both diabetes and the metabolic syndrome (Pan et al. 2010, 2012).

These alternative causal structures pose a challenge for drawing conclusions from observational data about whether PTSD truly causes cardiometabolic disease. Because randomizing individuals to developing PTSD is not plausible, we must seek to provide the most convincing possible evidence from observational studies (Vandenbroucke et al. 2016). Prospective longitudinal studies with in-depth measurement of potential confounders are needed. Studies that are cross-sectional or have limited measures of potential confounders cannot convincingly rule out confounding or reverse causation. However, when extensive data (including repeated assessments of relevant covariates) are available and well measured, statistical adjustment for confounders occurring before trauma or PTSD through direct inclusion in conventional models should mitigate bias due to confounding. Similarly, reverse causation is unlikely to explain associations between PTSD and cardiometabolic risk in prospective studies where individuals with these diseases at baseline are excluded. Prospective studies with repeated measures of both PTSD and cardiometabolic outcomes also offer the opportunity to examine the possibility of a bidirectional relationship. Cross-lagged models from longitudinal data in population-based samples with at least three follow-up waves have demonstrated 
bidirectional relationships between PTSD and other factors such as trauma exposure (Lowe et al. 2014), negative emotionality (Sadeh et al. 2015) and quality of life over time (Giacco et al. 2013). We are not aware of published studies employing such models for PTSD and medically verified health outcomes in longitudinal epidemiological samples, but such studies would undoubtedly provide important insight.

A critical issue for prospective longitudinal studies is accounting for time-varying confounding and mediation. Confounding occurs when a common prior cause explains the relationship between an exposure and an outcome. For example, low socio-economic status has been associated with increased risk of both CVD/T2D and PTSD and could be considered a potential confounder. Mediation occurs when a third variable, on the pathway between the exposure and the outcome, explains the observed relationship. For example, in scenario d of Fig. 1, PTSD increases smoking and smoking increases risk of CVD. Thus, smoking could be a mediator of the PTSD-CVD relationship.

Marginal structural models have revolutionized the epidemiological approach to time-varying confounding of time-varying exposures (Robins et al. 2000). These models have particular promise for understanding the PTSD-cardiometabolic relationship given that PTSD alters health behaviors but such behaviors may also increase risk of PTSD onset, persistence or remission. Such time-varying confounding could present a substantial threat to causal inference. For example, smoking may increase PTSD risk (van der Velden et al. 2008) and is a causal risk factor for CVD. Additionally, other research has clearly demonstrated that PTSD is associated with increased risk of initiating smoking (Koenen et al. 2006) and difficulty quitting (Koenen et al. 2008). The conventional method of adjusting for the confounding effects of smoking through direct inclusion in a regression model blocks the mediating pathway between PTSD and CVD, and underestimates the effect of PTSD. Furthermore, direct inclusion of health behaviors in regression models could allow unmeasured confounders of health behaviors and CVD to bias estimates (i.e. collider bias) people with PTSD who do not smoke may have some other advantages that help them avoid healthdamaging behaviors.

Having a substantial period of time elapse between PTSD assessments and incidence of cardiometabolic conditions may also help to rule out reverse causation, but such delays introduce the possibility of bias due to selective mortality and can also make it difficult to determine if there are potentially acute effects of PTSD on cardiometabolic events. With higher mortality rates among people with PTSD (Boscarino, 2006, 2008), individuals who survive long enough to develop conditions such as CVD may be a particularly 'hardy' sample. This type of selective survival could lead to underestimates of the effect of PTSD on cardiometabolic outcomes, but can at least partially be addressed with methods to account for attrition, such as inverse probability weighting (IPW). IPW weights respondents who remain in the sample based on observed covariates to create an analysed sample of survivors with the same covariate distribution as the original sample. Recent methods emphasize applications of IPW to estimate the so-called 'survivor average causal effect' (SACE), i.e. the effect of PTSD on cardiometabolic disease risk among people whose survival was not affected by PTSD (Tchetgen Tchetgen et al. 2012; Tchetgen Tchetgen, 2014). However, even with the most comprehensive feasible control for confounding, with observational data concerns can remain about unmeasured or residual confounding, or the possibility of prodromal disease driving associations.

Instrumental variable analysis is another powerful statistical method that may estimate unbiased causal effects of the exposure on the outcome even when there are unmeasured variables that confound the link between exposure and outcome. Instruments are factors that cause variation in the exposure of interest but do not directly affect the outcome of interest. In this context, an instrumental variable would be associated with PTSD but not cardiometabolic risk except through its association with PTSD (Greenland, 2000). Until recently, most instrumental variable analyses used factors such as policy changes (e.g. introduction of trauma counseling) or arbitrary institutional features (e.g. randomly assigned order of military draft) as sources of exogenous variation in exposure. Recently, applications using genetic variants as instrumental variables have also become popular. Mendelian randomization is a particular form of instrumental variable analysis that capitalizes on the fact that genotypes are assigned randomly when passed from parents to offspring; thus, population genotype distribution should be unrelated to confounders that might be relevant in observational studies (Smith \& Ebrahim, 2003). Genetic variants that influence a phenotype (e.g. PTSD) can be used as a natural experiment or instrumental variable for that phenotype.

Mendelian randomization could be used to assess evidence for shared genetic vulnerability to PTSD and cardiometabolic disease, reverse causation or direct causation. For example, a bidirectional Mendelian randomization approach would assess whether genetic variants that increase cardiometabolic disease risk also predict higher risk of PTSD: if not, this is evidence against reverse causation accounting for the link between PTSD and cardiometabolic disease documented in previous studies. Although an established genetic 
instrument for PTSD has yet to be identified, the PTSD working group of the Psychiatric Genomics Consortium is poised to identify genetic variants associated with PTSD and is developing polygenic models of PTSD that could be used as instruments (Logue et al. 2015). To our knowledge, only one study of PTSD has employed Mendelian randomization (Mustapic et al. 2014).

\section{Elucidating mechanisms to better understand risk}

Two pathways are commonly identified to explain how PTSD may increase risk of cardiometabolic (or other) diseases: behavioral and biological. PTSD may provoke unhealthy behaviors and/or produce neurobiological alterations that initiate relevant pathophysiological processes (Wentworth et al. 2013; Levine et al. 2014). Research clearly demonstrating that PTSD alters known mechanisms of cardiometabolic risk would provide compelling evidence that PTSD is indeed involved in the etiology of cardiometabolic disease. However, rigorous evidence demonstrating these causal associations is limited (Kibler, 2009; Wentworth et al. 2013).

Some of the strongest evidence to date (although mostly from observational studies) is in the domain of health behaviors or behavior-related conditions. To our knowledge, there are no randomized trials evaluating whether successful PTSD treatment leads to improved health-related behaviors. Cross-sectional work suggests that PTSD is associated with numerous behavioral risk factors and conditions for cardiometabolic disease, including cigarette smoking ( $\mathrm{Fu}$ et al. 2007), physical inactivity (Chwastiak et al. 2011), poor diet quality (Hall et al. 2015), obesity (Scott et al. 2008) and insomnia (Leskin et al. 2002). Furthermore, prospective studies have found associations of PTSD with increased likelihood of initiating smoking (Koenen et al. 2006), reduced likelihood of smoking cessation (Koenen et al. 2008), increased risk of weight gain and obesity (Perkonigg et al. 2009; Kubzansky et al. 2014), and medication non-adherence (Kronish et al. 2014).

Some work has specifically analysed the extent to which health behaviors may mediate the relationship between PTSD and other cardiometabolic risk factors. For example, in one study, greater PTSD symptoms were associated with reduced heart rate variability (a measure of autonomic function that is prognostic of CVD and mortality), and three health behaviors - cigarette smoking, alcohol overuse and sleep disturbance - accounted for $94 \%$ of the shared variance between PTSD symptoms and heart rate variability (Dennis et al. 2014). In our own studies examining the associations of PTSD with incident T2D and CVD among women, we found that behavior-related risk factors accounted for a sizeable portion of these relationships. For example, elevated body mass index accounted for $14 \%$ of the PTSD symptoms-T2D relationship (Roberts et al. 2015), and a range of health behaviors and medical risk factors (e.g. body mass index, diet quality, smoking) explained nearly half of the association of elevated PTSD symptoms with CVD (Sumner et al. 2015). Thus, evidence increasingly suggests that behavioral risk factors, in part, mediate the PTSD-cardiometabolic disease relationship. However, behavior-related factors rarely fully attenuate associations, suggesting that other unmeasured behaviors or biological processes may be at play.

Substantial research has identified neurobiological alterations associated with high levels of PTSD symptoms (Pitman et al. 2012). Thus, it is plausible that PTSD, by recurrent triggering of a biological stress response and overactivation of biological processes associated with hypervigilance, could directly alter processes involved in the pathophysiology of cardiometabolic disease. Disrupted regulation of stress hormone release by the hypothalamic-pituitary-adrenal (HPA) axis and the sympathetic-adrenal-medullary system is commonly observed in PTSD (Tsigos \& Chrousos, 2002; de Kloet et al. 2006; Yehuda, 2006; Blechert et al. 2007), and other work has demonstrated that these disruptions can lead to a cascade of deleterious effects on immune, metabolic and cardiovascular systems. Dysregulation of the HPA axis and the sympathetic nervous system can contribute to hypercoagulability, elevated cardiac reactivity, unhealthy lipid profiles, immune dysfunction, chronic inflammation and endothelial damage, all processes implicated in increasing cardiometabolic disease risk (Wentworth et al. 2013; Brouwers et al. 2016). Most evidence to date comes from cross-sectional studies, and indicates that PTSD is associated with more unhealthy levels of biomarkers related to the processes described above. Cardiometabolic biomarkers that have been linked to PTSD include markers of chronic inflammation (e.g. C-reactive protein, interleukin-6, tumor necrosis factor- $\alpha$ ) (Smith et al. 2011; Baker et al. 2012; Passos et al. 2015; Brouwers et al. 2016), elevated coagulation (Von Känel et al. 2006; 2010) and endothelial damage (von Känel et al. 2008; Plantinga et al. 2013), as well as elevated lipids (Kagan et al. 1999; Karlovic et al. 2004; Maia et al. 2008). These findings are congruent with other work that suggests that high distress in various forms may induce autonomic imbalance and reduce parasympathetic tone, which in turn is associated with increased risk of numerous pathological conditions, including CVD and premature mortality (Thayer \& Brosschot, 2005).

Although many of the extant biomarker studies provide evidence suggestive of a link between PTSD and 
biological indicators of cardiometabolic risk, shortcomings of these studies limit the conclusions that can be drawn. First, many studies were conducted with small samples which are not informative if results are null (Gill et al. 2008; Smith et al. 2011; Pace et al. 2012), although there are some exceptions (Spitzer et al. 2010; Ahmadi et al. 2011). Second, studies have not consistently reported whether participants with PTSD are free of relevant chronic diseases. Thus, the PTSD-biomarker relationship could be due to higher prevalence of chronic disease already present in the PTSD cases and not due to PTSD itself. Third, some studies have failed to assess effects of trauma exposure (Su et al. 2015) separately from PTSD (Pace et al. 2012). Because there is ongoing debate as to whether trauma alone might cause biological dysregulation, it is not yet clear whether PTSD per se is driving the associations with biomarkers (Seckl \& Meaney, 2006; Seckl, 2007; Sledjeski et al. 2008; Yehuda et al. 2010; Dudley et al. 2011). Fourth, given most studies are cross-sectional, they cannot provide clear evidence of the directionality of these associations or distinguish whether: (1) PTSD induces unhealthy biomarker activity; (2) unhealthy levels of biomarkers lead to increased PTSD symptoms; or (3) apparent relationships between unhealthy levels of biomarkers and PTSD are due to shared causes (e. g. genetic factors). For example, longitudinal studies suggest that poorer physical health (LeardMann et al. 2009) and some forms of biological dysregulation linked to PTSD, including higher numbers of glucocorticoid receptors (van Zuiden et al. 2011, 2012) and hypersensitive startle response (Pole et al. 2009), precede and predict, rather than result from, PTSD (Rusiecki et al. 2012; van Zuiden et al. 2012). However, bidirectionality between PTSD and dysregulated biological processes is also possible, making it even more challenging to disentangle cause from effect. For example, bidirectionality has been observed in the association between depression and C-reactive protein (Matthews et al. 2010); such relationships may also be at play with PTSD.

\section{Delving deeper into the PTSD phenotype within and across time}

Many of the extant studies on PTSD and cardiometabolic disease have compared individuals with and without PTSD diagnoses. However, PTSD is a complex and heterogeneous phenotype, and this categorical approach does not fully capture the richness of the PTSD construct (Forbes et al. 2011; Zoellner et al. 2014). Going forward, three approaches may help us better understand how aspects of PTSD phenomenology contribute to chronic disease risk.

First, PTSD is constructed from multiple symptom dimensions that may have distinct effects on cardiometabolic risk. Fear symptoms reflect an alarm response to perceived danger, and include re-experiencing (e.g. nightmares), active avoidance (e.g. avoiding trauma-related thoughts) and anxious arousal (e.g. hypervigilance) symptoms of PTSD (Forbes et al. 2011; Zoellner et al. 2014). In contrast, dysphoria symptoms reflect low positive affect, and encompass symptoms of emotional numbing (e.g. restricted affect) and dysphoric arousal (e.g. concentration difficulties). These dimensions are thought to be useful for distinguishing specific $v$. non-specific aspects of PTSD. Whereas the dysphoria component of PTSD is shared with other psychopathology (e.g. depression), fear responses are thought to be a core feature of PTSD (Forbes et al. 2010, 2011; Zoellner et al. 2014). Indeed, a recent review called for studying fear responses to trauma to improve the specificity of PTSD assessment (Zoellner et al. 2014).

Numerous confirmatory factor analyses indicate that fear and dysphoria symptoms form valid and distinct (albeit correlated) dimensions of PTSD (Grant et al. 2008; Forbes et al. 2010, 2011), and models of PTSD that differentiate between factors within the fear and dysphoria dimensions have been supported as well (Elhai et al. 2011; Harpaz-Rotem et al. 2014; Armour et al. 2015). Focusing on dimensions of PTSD - rather than a single PTSD construct - may help shed light on how PTSD contributes to risk for cardiometabolic disease, as PTSD symptom dimensions may differ in the extent to which they increase chronic disease risk via biological $v$. behavioral mechanisms. For example, by promoting autonomic nervous system dysregulation (particularly sympathetic nervous system hyperactivity), post-traumatic fear responses may contribute to CVD risk by promoting increased blood pressure, coagulation, platelet aggregation and inflammatory cytokines (Lefkowitz et al. 2000; Bedi \& Arora, 2007; Abboud et al. 2012; Edmondson \& Cohen, 2013; Wentworth et al. 2013). In contrast, elevated symptoms of dysphoria after trauma may be more likely than fear symptoms to promote withdrawal and failure to engage in health-promoting behaviors (e.g. physical activity, medication adherence). However, few studies have tried to tease these domains apart. Further research examining the relative contributions of the mechanisms by which PTSD dimensions may lead to cardiometabolic disease is needed.

Second, greater appreciation of the course of PTSD over time may also improve understanding of the physical health risks associated with the disorder. Several studies suggest that there is a dose-response association between PTSD severity and risk for cardiometabolic conditions, with the most severe symptoms associated with the greatest elevation in disease risk (Kubzansky et al. 2007, 2009; Roberts et al. 2015). Work that takes into consideration other aspects of 
PTSD presentation, including the trajectory of symptom development, is also of interest. For example, several 'longitudinal phenotypes' of PTSD that reflect the trajectory of PTSD symptoms over time after trauma exposure have been documented (e.g. rapid remitting, slow remitting, delayed onset, chronic/non-remitting) (Galatzer-Levy et al. 2013; Santiago et al. 2013). However, studies that examine how these various PTSD trajectories relate to physical health outcomes are lacking. Moreover, how trajectories of PTSD symptoms may relate to time-varying confounding or mediation has not been examined in the context of physical health outcomes. A more nuanced understanding of how patterns of PTSD development and expression over time relate to indicators of physical health may provide greater precision in understanding what aspects of PTSD are most pernicious for health. Information generated from such research also can help health care professionals identify who should be targeted for prevention.

Third, future research should examine how persistence $v$. remission of PTSD influences risk. PTSD is frequently a chronic condition, with meta-analytic evidence suggesting that, on average, over half of individuals with PTSD (56\%) do not remit from the disorder naturally after a mean of more than 3 years (Morina et al. 2014). Epidemiological research indicates that more than a third of individuals continue to have symptoms of PTSD 30 years after onset of the disorder (Chapman et al. 2012). Although this topic has not been explored extensively, there is some evidence that greater chronicity is associated with worse cardiovascular outcomes. For example, one meta-analysis examined the association between PTSD chronicity and basal heart rate by comparing individuals who had PTSD for either more than 12 years or less than 8 years with trauma-exposed individuals without PTSD (Buckley \& Kaloupek, 2001). Effect size comparisons for elevations in heart rate were larger for individuals with PTSD for more than 12 years than for individuals with PTSD for less than 8 years.

Research examining how remitted status relates to risk for cardiometabolic disease is also needed. One recent study reported that veterans with current - but not remitted - PTSD had lower heart rate variability compared with veterans without PTSD (Shah et al. 2013). In our study of PTSD and weight gain, while women with trauma and ongoing symptoms had significantly excess odds of overweight or obesity, those with remitted symptoms did not. If future research can confirm that individuals with remitted PTSD have lower cardiometabolic risk compared with those with current PTSD, this would suggest that treating PTSD might reduce cardiometabolic disease risk. Such findings would provide a promising foundation for supporting more widespread dissemination of empirically supported treatments for PTSD. Greater access to efficacious treatment for PTSD to improve emotional health is an important goal in its own right; demonstrating that treatment would also improve cardiometabolic health would provide extra impetus for this initiative.

\section{New research directions}

Indeed, whether effective treatment of PTSD can prevent or mitigate the likelihood of developing cardiometabolic disease is a key outstanding question in the literature. The strongest design to answer this question would be a randomized clinical trial whereby individuals are randomized to PTSD treatment or placebo, and then followed to assess whether treatment reduces likelihood of developing disease. However, such a trial would be highly expensive, unethical and time consuming, and is unlikely to be feasible at present. Thus, we propose four other methodological approaches that are more feasible and could begin to address the limitations of current knowledge highlighted here regarding causal associations and mechanisms (see Table 2). The most rigorous designs that could currently be harnessed leverage existing randomized trials of PTSD treatment. One possibility is to add assessments of cardiometabolic-related biomarkers and behaviors to new clinical trials of PTSD treatment that have not yet started (Cohen et al. 2004; Cloitre et al. 2010). Ideally, biomarker assessment would be conducted prior to and after treatment, perhaps even at repeated intervals after treatment. It would then be possible to monitor if treatment was associated with less deterioration (or ability to maintain healthier levels) of cardiometabolic risk biomarkers.

A second possibility is to re-contact patients who participated in completed PTSD treatment trials and obtain from these individuals measures of health behaviors, risk markers and physical health status. This would facilitate testing if those who were successfully treated engage in fewer unhealthy behaviors, have healthier levels of risk markers and better physical health status relative to those who did not receive treatment. In both types of studies, data from a randomized design could provide strong evidence regarding the potential efficacy of PTSD treatment on cardiometabolic risk. However, one potential challenge to this approach is differential follow-up by treatment effectiveness (i.e. individuals whose PTSD was not successfully treated are more likely to be lost to followup). Moreover, investigators would have had to have consent to re-contact participants included in their informed consents in order to conduct such a study.

Another set of methodological approaches leverages existing observational longitudinal cohort studies. 
Table 2. Advantages and disadvantages of research designs for added insight into the PTSD-cardiometabolic disease relationship

\begin{tabular}{|c|c|c|}
\hline Type of research & Advantages & Disadvantages \\
\hline \multicolumn{3}{|l|}{ 'Gold standard' for assessing causality } \\
\hline $\begin{array}{l}\text { Randomized trial of PTSD treatment in persons with PTSD, } \\
\text { followed over time to assess cardiometabolic risk }\end{array}$ & $\begin{array}{l}\text { Strong causal inference (randomization) } \\
\text { Excellent ascertainment of cardiometabolic disease risk } \\
\text { at baseline }\end{array}$ & $\begin{array}{l}\text { Unethical to randomize to no treatment; therefore, } \\
\text { treatment arms may not differ in PTSD severity or } \\
\text { duration } \\
\text { Costly } \\
\text { Long time period before results are available } \\
\text { Potential bias from self-selection for enrollment and } \\
\text { from dropout }\end{array}$ \\
\hline \multicolumn{3}{|l|}{$\begin{array}{l}\text { Other rigorous methodological approaches for assessing } \\
\text { causality }\end{array}$} \\
\hline $\begin{array}{l}\text { 1. Leverage existing RCT: at start of new randomized trials of } \\
\text { PTSD treatment, add cardiometabolic-relevant biomarker } \\
\text { and behavioral measures and follow up individuals in the } \\
\text { various treatment groups; compare differences in } \\
\text { cardiometabolic risk across groups }\end{array}$ & $\begin{array}{l}\text { Strong causal inference (randomization) } \\
\text { Subject may be his/her own comparator if measures of } \\
\text { cardiometabolic risk are available prior to treatment } \\
\text { (eliminating potential confounding by factors that do } \\
\text { not vary during the study time-frame) }\end{array}$ & $\begin{array}{l}\text { Only trials that show difference in PTSD outcomes by } \\
\text { treatment arm can be used } \\
\text { Trials may not be sufficiently large (and therefore may } \\
\text { be underpowered) to assess cardiometabolic disease } \\
\text { risk by treatment arm }\end{array}$ \\
\hline & Moderate cost & $\begin{array}{l}\text { Including measures of cardiometabolic risk could add } \\
\text { substantial cost and burden }\end{array}$ \\
\hline $\begin{array}{l}\text { 2. Leverage existing RCT: among completed randomized trials } \\
\text { of PTSD treatment, re-contact participants who participated } \\
\text { in the trial and ascertain current cardiometabolic disease } \\
\text { status or risk }\end{array}$ & Strong causal inference (randomization) & $\begin{array}{l}\text { Only trials that show difference in PTSD outcomes by } \\
\text { treatment arm can be used } \\
\text { Trials may not be sufficiently large (and therefore may } \\
\text { be underpowered) to assess cardiometabolic disease } \\
\text { risk by treatment arm } \\
\text { May be difficult to re-contact trial participants, possibly } \\
\text { resulting in bias and/or small } n^{\prime} \text { s }\end{array}$ \\
\hline $\begin{array}{l}\text { 3. Secondary analysis using longitudinal observational design: } \\
\text { cohort study that includes individuals who have and have } \\
\text { not received treatment for PTSD and levels of } \\
\text { cardiometabolic risk are compared across groups }\end{array}$ & $\begin{array}{l}\text { Inexpensive, utilizes existing data } \\
\text { Potential short time-frame for results if outcomes have } \\
\text { already occurred }\end{array}$ & $\begin{array}{l}\text { Treatment seeking may be an indicator of PTSD } \\
\text { severity } \\
\text { Treatment seeking may result from factors that also } \\
\text { affect cardiometabolic risk, e.g. socio-economic status, } \\
\text { self-efficacy (confounding may exist and many } \\
\text { confounders may not have been measured) } \\
\text { May be difficult to find existing studies that include } \\
\text { information on whether individuals received } \\
\text { treatment for PTSD and if it was successful }\end{array}$ \\
\hline $\begin{array}{l}\text { 4. Secondary analysis using longitudinal observational design: } \\
\text { cohort study that includes biomarkers of cardiometabolic } \\
\text { disease risk in persons before and after PTSD onset }\end{array}$ & $\begin{array}{l}\text { Subject is his/her own comparator (eliminating } \\
\text { potential confounding by factors that do not vary } \\
\text { during the study time-frame) }\end{array}$ & $\begin{array}{l}\text { Potential bias by factors that vary within the study } \\
\text { time-frame (e.g. new trauma exposure) }\end{array}$ \\
\hline
\end{tabular}

PTSD, Post-traumatic stress disorder; RCT, randomized controlled trial. 
Studies with information about whether participants were effectively treated for PTSD, as well as information on cardiometabolic disease or risk factors, could provide preliminary evidence regarding whether PTSD treatment reduces cardiometabolic risk. A drawback of this design is that such a study would be vulnerable to bias from confounding by indication. Individuals with more severe PTSD are more likely to seek treatment; thus, treatment may indicate PTSD severity. However, propensity score analyses, IPW and other statistical techniques based on covariate adjustment can mitigate such potential confounding (Klungel et al. 2004).

An additional approach in this arena would leverage data from studies with measures of PTSD date of onset as well as repeated measures of biomarkers of cardiometabolic risk and relevant health behaviors. With biological and behavioral measures available before and after PTSD onset, change in risk in relation to PTSD onset can be assessed. Pooling biomarker data across multiple cohorts, as has been done in genomics, would further advance the field by increasing sample size, reducing issues of both type 1 and type 2 error, and ultimately providing more robust evidence of whether observed associations between PTSD and such markers are causal.

All four methodological approaches - measurement add-ons to new trials, re-contacting participants from past trials, observational studies comparing treated with untreated, and observational studies with measures spanning onset of PTSD - are relatively feasible. They draw on or extend data being collected from existing longitudinal or experimental studies. By obtaining cardiometabolic risk measures before and after, or at least clearly after, PTSD onset or treatment, the likelihood of reverse causation is minimized. Two of the suggested designs use individuals as their own comparator, thus eliminating possible influence of confounding factors that do not vary within individuals over the study period (Weisskopf et al. 2015). Additionally, two of the designs leverage the randomization to treatment found in most clinical trials to further improve causal inference. Together, these types of studies may establish more clearly that: (1) PTSD treatment is related to reduced risk of subsequent cardiometabolic disease; (2) increased likelihood of adverse health behaviors or biological dysregulation occurs after onset of PTSD; or (3) cardiometabolic risk behaviors or biomarkers are improved (or are less likely to deteriorate) after PTSD treatment.

Moving forward, considering how trauma exposure and the development of PTSD translate into cardiometabolic risk over the life course may also provide important insight regarding the interplay between mental and physical health. If mental health problems are an early warning sign of physical deterioration, this may alter approaches to prevention and intervention, particularly when trauma is known to have occurred. Moreover, there may be periods during which exposure to adversity or psychological distress is highly toxic in relation to physical health, or periods during which damage incurred is more difficult to reverse. One recent study found that high levels of distress in childhood, even when distress was lower during adulthood, had substantial impact on cardiometabolic health in middle adulthood (Winning et al. 2015). Other research has similarly suggested that exposure to adversity during pregnancy and early childhood leads to damage relatively early on, and may be especially deleterious for long-term health (Ehlert, 2013). Furthermore, although most studies have focused on PTSD and disease incidence in middle-aged and older adults, there is some evidence that childhood abuse is associated with higher diastolic blood pressure in adolescence (Gooding et al. 2016) and hypertension in young adulthood (Suglia et al. 2014). Thus, it appears that potentially toxic health effects of PTSD are set in motion relatively early. Additional research is needed to examine how both trauma and PTSD in youth relate to myriad indicators of cardiometabolic risk in order to develop a more comprehensive understanding of when physical health risks associated with PTSD begin to manifest and how enduring these risks may be.

Future research should examine the clinical utility of screening for PTSD in assessing PTSD risk. This research would need to consider whether including PTSD, in addition to standard CVD risk factors, improves risk prediction and/or treatment matching. Increasingly cardiovascular medicine has recognized early-life origins of CVD (Lloyd-Jones et al. 2010). This recognition extends beyond effects of behavior to psychological factors as well. In fact, in a recent scientific statement from the American Heart Association (Goldstein et al. 2015), major depressive disorder and bipolar disorder in youth were classified as Expert Panel tier II moderate-risk conditions associated with accelerated atherosclerosis and early CVD. This appreciation that psychopathology early in life can have negative consequences for physical health in youth and adulthood may one day be expanded to include PTSD. Ultimately, this research can inform prevention and treatment resources in an age of targeted medicine.

\section{Acknowledgements}

This work was supported by the National Institutes of Health (to K.C.K., R01MH078928; to K.C.K., L.D. K. and A.W., R01MH101269; NHS II infrastructure, 
UM1CA176726; to J.A.S., K01HL130650; and to P.G., T32MH017119) and by the Yerby Postdoctoral Fellowship Program (to P.G.).

\section{Declaration of Interest}

None.

\section{References}

Abboud FM, Harwani SC, Chapleau MW (2012). Autonomic neural regulation of the immune system implications for hypertension and cardiovascular disease. Hypertension 59, 755-762.

Abrams D, Manstead ASR (1981). A test of theories of social facilitation using a musical task. British Journal of Social Psychology 20, 271-278.

Ahmadi N, Hajsadeghi F, Mirshkarlo HB, Budoff M, Yehuda R, Ebrahimi R (2011). Post-traumatic stress disorder, coronary atherosclerosis, and mortality. American Journal of Cardiology 108, 29-33.

American Heart Association (2013). Stress and Blood Pressure (http://www.heart.org/HEARTORG/).

Armour C, Tsai J, Durham TA, Charak R, Biehn TL, Elhai JD, Pietrzak RH (2015). Dimensional structure of DSM-5 posttraumatic stress symptoms: support for a hybrid anhedonia and externalizing behaviors model. Journal of Psychiatric Research 61, 106-113.

Baker DG, Nievergelt CM, O'Connor DT (2012). Biomarkers of PTSD: neuropeptides and immune signaling. Neuropharmacology 62, 663-673.

Bedi US, Arora R (2007). Cardiovascular manifestations of posttraumatic stress disorder. Journal of the National Medical Association 99, 642-649.

Beristianos MH, Yaffe K, Cohen B, Byers AL (2016). PTSD and risk of incident cardiovascular disease in aging veterans. American Journal of Geriatric Psychiatry 24, 192-200.

Blechert J, Michael T, Grossman P, Lajtman M, Wilhelm FH (2007). Autonomic and respiratory characteristics of posttraumatic stress disorder and panic disorder. Psychosomatic Medicine 69, 935-943.

Boscarino JA (2006). Posttraumatic stress disorder and mortality among U.S. Army veterans 30 years after military service. Annals of Epidemiology 16, 248-256.

Boscarino JA (2008). A prospective study of PTSD and early-age heart disease mortality among Vietnam veterans: implications for surveillance and prevention. Psychosomatic Medicine 70, 668-676.

Boscarino JA, Chang J (1999). Electrocardiogram abnormalities among men with stress-related psychiatric disorders: implications for coronary heart disease and clinical research. Annals of Behavioral Medicine 21, 227-234.

Boyko EJ, Jacobson IG, Smith B, Ryan MAK, Hooper TI, Amoroso PJ, Gackstetter GD, Barrett-Connor E, Smith TC, Team f. t. MCS (2010). Risk of diabetes in U.S. military service members in relation to combat deployment and mental health. Diabetes Care 33, 1771-1777.
Brouwers CJ, Wolf JM, von Känel R (2016). Inflammatory markers in PTSD. In Comprehensive Guide to Post-Traumatic Stress Disorders (ed. C Martin, V Preedy and V Patel), pp. 979-993. Springer: New York.

Buckley TC, Kaloupek DG (2001). A meta-analytic examination of basal cardiovascular activity in posttraumatic stress disorder. Psychosomatic Medicine 63, 585-594.

Chapman C, Mills K, Slade T, McFarlane AC, Bryant R, Creamer M, Silove D, Teesson M (2012). Remission from post-traumatic stress disorder in the general population. Psychological Medicine 42, 1695-1703.

Chen M-H, Pan T-L, Li C-T, Lin W-C, Chen Y-S, Lee Y-C, Tsai S-J, Hsu J-W, Huang K-L, Tsai C-F (2015). Risk of stroke among patients with post-traumatic stress disorder: nationwide longitudinal study. British Journal of Psychiatry 206, 302-307.

Chwastiak LA, Rosenheck RA, Kazis LE (2011). Association of psychiatric illness and obesity, physical inactivity, and smoking among a national sample of veterans. Psychosomatics 52, 230-236.

Cloitre M, Stovall-McClough KC, Nooner K, Zorbas P, Cherry S, Jackson CL, Gan W, Petkova E (2010). Treatment for PTSD related to childhood abuse: a randomized controlled trial. American Journal of Psychiatry 167, 915-924.

Cohen JA, Deblinger E, Mannarino AP, Steer RA (2004). A multisite, randomized controlled trial for children with sexual abuse-related PTSD symptoms. Journal of the American Academy of Child and Adolescent Psychiatry 43, 393-402.

de Kloet CS, Vermetten E, Geuze E, Kavelaars A, Heijnen CJ, Westenberg HG (2006). Assessment of HPA-axis function in posttraumatic stress disorder: pharmacological and non-pharmacological challenge tests, a review. Journal of Psychiatric Research 40, 550-567.

Dennis PA, Watkins LL, Calhoun PS, Oddone A, Sherwood A, Dennis MF, Rissling MB, Beckham JC (2014). Posttraumatic stress, heart rate variability, and the mediating role of behavioral health risks. Psychosomatic Medicine 76, 629-637.

Dong M, Giles WH, Felitti VJ, Dube SR, Williams JE, Chapman DP, Anda RF (2004). Insights into causal pathways for ischemic heart disease: adverse childhood experiences study. Circulation 110, 1761-1766.

Dube SR, Felitti VJ, Dong M, Giles WH, Anda RF (2003). The impact of adverse childhood experiences on health problems: evidence from four birth cohorts dating back to 1900. Preventive Medicine 37, 268-277.

Dudley KJ, Li X, Kobor MS, Kippin TE, Bredy TW (2011). Epigenetic mechanisms mediating vulnerability and resilience to psychiatric disorders. Neuroscience and Biobehavioral Reviews 35, 1544-1551.

Edmondson D, Cohen BE (2013). Posttraumatic stress disorder and cardiovascular disease. Progress in Cardiovascular Diseases 55, 548-556.

Edmondson D, Richardson S, Falzon L, Davidson KW, Mills MA, Neria Y (2012). Posttraumatic stress disorder prevalence and risk of recurrence in acute coronary syndrome patients: a meta-analytic review. PLOS ONE 7, e38915. 
Ehlert U (2013). Enduring psychobiological effects of childhood adversity. Psychoneuroendocrinology 38, 1850-1857.

El-Gabalawy R, Mackenzie CS, Pietrzak RH, Sareen J (2014). A longitudinal examination of anxiety disorders and physical health conditions in a nationally representative sample of U.S. older adults. Experimental Gerontology 60, $46-56$.

Elhai JD, Biehn TL, Armour C, Klopper JJ, Frueh BC, Palmieri PA (2011). Evidence for a unique PTSD construct represented by PTSD's D1-D3 symptoms. Journal of Anxiety Disorders 25, 340-345.

Eraly SA, Nievergelt CM, Maihofer AX, Barkauskas DA, Biswas N, Agorastos A, O'Connor DT, Baker DG (2014). Assessment of plasma C-reactive protein as a biomarker of posttraumatic stress disorder risk. JAMA Psychiatry 71, 423-431.

Felitti VJ, Anda RF, Nordenberg D, Williamson DF, Spitz AM, Edwards V, Koss MP, Marks JS (1998). Relationship of childhood abuse and household dysfunction to many of the leading causes of death in adults. The Adverse Childhood Experiences (ACE) Study. American Journal of Preventive Medicine 14, 245-258.

Forbes D, Lockwood E, Elhai JD, Creamer M, O'Donnell M, Bryant R, McFarlane A, Silove D (2011). An examination of the structure of posttraumatic stress disorder in relation to the anxiety and depressive disorders. Journal of Affective Disorders 132, 165-172.

Forbes D, Parslow R, Creamer M, O'Donnell M, Bryant R, McFarlane A, Silove D, Shalev A (2010). A longitudinal analysis of posttraumatic stress disorder symptoms and their relationship with fear and anxious-misery disorders: implications for DSM-V. Journal of Affective Disorders 127, 147-152.

Fu SS, McFall M, Saxon AJ, Beckham JC, Carmody TP, Baker DG, Joseph AM (2007). Post-traumatic stress disorder and smoking: a systematic review. Nicotine and Tobacco Research 9, 1071-1084.

Galatzer-Levy IR, Ankri Y, Freedman S, Israeli-Shalev Y, Roitman P, Gilad M, Shalev AY (2013). Early PTSD symptom trajectories: persistence, recovery, and response to treatment: results from the Jerusalem Trauma Outreach and Prevention Study (J-TOPS). PLOS ONE 8, e70084.

Giacco D, Matanov A, Priebe S (2013). Symptoms and subjective quality of life in post-traumatic stress disorder: a longitudinal study. PLOS ONE 8, e60991.

Gill J, Vythilingam M, Page GG (2008). Low cortisol, high DHEA, and high levels of stimulated TNF $\alpha$, and IL-6 in women with PTSD. Journal of Traumatic Stress 21, 530-539.

Godfrey KM, Lindamer LA, Mostoufi S, Afari N (2013). Posttraumatic stress disorder and health: a preliminary study of group differences in health and health behaviors. Annals of General Psychiatry 12, 30.

Goldstein BI, Carnethon MR, Matthews KA, McIntyre RS, Miller GE, Raghuveer G, Stoney CM, Wasiak H, McCrindle BW (2015). Major depressive disorder and bipolar disorder predispose youth to accelerated atherosclerosis and early cardiovascular disease: a scientific statement from the American Heart Association. Circulation 132, 965-986.
Gooding HC, Milliren CE, Austin SB, Sheridan MA, McLaughlin KA (2016). Child abuse, resting blood pressure, and blood pressure reactivity to psychosocial stress. Journal of Pediatric Psychology 41, 5-14.

Gradus JL, Farkas DK, Svensson E, Ehrenstein V, Lash TL, Milstein A, Adler N, Sørensen HT (2015). Associations between stress disorders and cardiovascular disease events in the Danish population. BMJ Open 5, e009334.

Grant DM, Beck JG, Marques L, Palyo SA, Clapp JD (2008). The structure of distress following trauma: posttraumatic stress disorder, major depressive disorder, and generalized anxiety disorder. Journal of Abnormal Psychology 117, 662-672.

Greenland S (2000). An introduction to instrumental variables for epidemiologists. International Journal of Epidemiology 29, 722-729.

Hall KS, Hoerster KD, Yancy Jr. WS (2015). Post-traumatic stress disorder, physical activity, and eating behaviors. Epidemiologic Reviews 37, 103-115.

Harpaz-Rotem I, Tsai J, Pietrzak RH, Hoff R (2014). The dimensional structure of posttraumatic stress symptomatology in 323903 US veterans. Journal of Psychiatric Research 49, 31-36.

Jordan HT, Miller-Archie SA, Cone JE, Morabia A, Stellman SD (2011). Heart disease among adults exposed to the September 11, 2001 World Trade Center disaster: results from the World Trade Center Health Registry. Preventive Medicine 53, 370-376.

Kagan BL, Leskin G, Haas B, Wilkins J, Foy D (1999). Elevated lipid levels in Vietnam veterans with chronic posttraumatic stress disorder. Biological Psychiatry 45, 374-377.

Karlovic D, Buljan D, Martinac M, Marcinko D (2004). Serum lipid concentrations in Croatian veterans with post-traumatic stress disorder, post-traumatic stress disorder comorbid with major depressive disorder, or major depressive disorder. Journal of Korean Medical Science 19, 431-436.

Kessler RC, Berglund P, Demler O, Jin R, Merikangas KR, Walters EE (2005). Lifetime prevalence and age-of-onset distributions of DSM-IV disorders in the National Comorbidity Survey Replication. Archives of General Psychiatry 62, 593-602.

Kibler JL (2009). Posttraumatic stress and cardiovascular disease risk. Journal of Trauma and Dissociation 10, 135-150.

Klungel OH, Martens EP, Psaty BM, Grobbee DE, Sullivan SD, Stricker BHC, Leufkens HGM, de Boer A (2004). Methods to assess intended effects of drug treatment in observational studies are reviewed. Journal of Clinical Epidemiology 57, 1223-1231.

Koenen KC, Hitsman B, Lyons MJ, Stroud L, Niaura R, McCaffery J, Goldberg J, Eisen SA, True W, Tsuang M (2006). Posttraumatic stress disorder and late-onset smoking in the Vietnam era twin registry. Journal of Consulting and Clinical Psychology 74, 186.

Koenen KC, Moffitt TE, Poulton R, Martin J, Caspi A (2007). Early childhood factors associated with the development of post-traumatic stress disorder: results from a longitudinal birth cohort. Psychological Medicine 37, 181-192. 
Koenen KC, Stellman SD, Sommer JF, Stellman JM (2008). Persisting posttraumatic stress disorder symptoms and their relationship to functioning in Vietnam veterans: a 14year follow-up. Journal of Traumatic Stress 21, 49-57.

Kronish IM, Lin JJ, Cohen BE, Voils CI, Edmondson D (2014). Posttraumatic stress disorder and medication nonadherence in patients with uncontrolled hypertension. JAMA Internal Medicine 174, 468-470.

Kubzansky LD, Bordelois P, Jun HJ, Roberts AL, Cerda M, Bluestone N, Koenen KC (2014). The weight of traumatic stress: a prospective study of posttraumatic stress disorder symptoms and weight status in women. JAMA Psychiatry 71, 44-51.

Kubzansky LD, Koenen KC, Jones C, Eaton WW (2009). A prospective study of posttraumatic stress disorder symptoms and coronary heart disease in women. Health Psychology 28, 125-130.

Kubzansky LD, Koenen KC, Spiro III A, Vokonas PS, Sparrow D (2007). Prospective study of posttraumatic stress disorder symptoms and coronary heart disease in the Normative Aging Study. Archives of General Psychiatry 64, 109-116.

LeardMann CA, Smith TC, Smith B, Wells TS, Ryan MA (2009). Baseline self reported functional health and vulnerability to post-traumatic stress disorder after combat deployment: prospective US military cohort study. BMJ 338, b1273.

Lefkowitz RJ, Rockman HA, Koch WJ (2000). Catecholamines, cardiac $\beta$-adrenergic receptors, and heart failure. Circulation 101, 1634-1637.

Leskin GA, Woodward SH, Young HE, Sheikh JI (2002). Effects of comorbid diagnoses on sleep disturbance in PTSD. Journal of Psychiatric Research 36, 449-452.

Levine AB, Levine LM, Levine TB (2014). Posttraumatic stress disorder and cardiometabolic disease. Cardiology 127, $1-19$.

Lloyd-Jones DM, Hong Y, Labarthe D, Mozaffarian D, Appel LJ, Van Horn L, Greenlund K, Daniels S, Nichol G, Tomaselli GF (2010). Defining and setting national goals for cardiovascular health promotion and disease reduction: the American Heart Association's strategic impact goal through 2020 and beyond. Circulation 121, 586-613.

Logue MW, Amstadter AB, Baker DG, Duncan L, Koenen KC, Liberzon I, Miller MW, Morey RA, Nievergelt CM, Ressler KJ (2015). The Psychiatric Genomics Consortium Posttraumatic Stress Disorder Workgroup: posttraumatic stress disorder enters the age of large-scale genomic collaboration. Neuropsychopharmacology 40, 2287-2297.

Lohr JB, Palmer BW, Eidt CA, Aailaboyina S, Mausbach BT, Wolkowitz OM, Thorp SR, Jeste DV (2015). Is post-traumatic stress disorder associated with premature senescence? A review of the literature. American Journal of Geriatric Psychiatry 23, 709-725.

Lowe SR, Walsh K, Uddin M, Galea S, Koenen KC (2014). Bidirectional relationships between trauma exposure and posttraumatic stress: a longitudinal study of Detroit residents. Journal of Abnormal Psychology 123, 533-544.

Maia DB, Marmar CR, Mendlowicz MV, Metzler T, Nobrega A, Peres MC, Coutinho ES, Volchan E, Figueira I
(2008). Abnormal serum lipid profile in Brazilian police officers with post-traumatic stress disorder. Journal of Affective Disorders 107, 259-263.

Matthews KA, Schott LL, Bromberger JT, Cyranowski JM, Everson-Rose SA, Sowers M (2010). Are there bi-directional associations between depressive symptoms and C-reactive protein in mid-life women? Brain, Behavior, and Immunity 24, 96-101.

Morina N, Wicherts JM, Lobbrecht J, Priebe S (2014). Remission from post-traumatic stress disorder in adults: a systematic review and meta-analysis of long term outcome studies. Clinical Psychology Review 34, 249-255.

Mustapic M, Maihofer AX, Mahata M, Chen Y, Baker DG, O'Connor DT, Nievergelt CM (2014). The catecholamine biosynthetic enzyme dopamine $\beta$-hydroxylase (DBH): first genome-wide search positions trait-determining variants acting additively in the proximal promoter. Human Molecular Genetics 23, 6375-6384.

Pace TW, Wingenfeld K, Schmidt I, Meinlschmidt G, Hellhammer DH, Heim CM (2012). Increased peripheral NF- $\kappa$ B pathway activity in women with childhood abuse-related posttraumatic stress disorder. Brain, Behavior, and Immunity 26, 13-17.

Pan A, Keum N, Okereke OI, Sun Q, Kivimaki M, Rubin RR, Hu FB (2012). Bidirectional association between depression and metabolic syndrome: a systematic review and meta-analysis of epidemiological studies. Diabetes Care 35, 1171-1180.

Pan A, Lucas M, Sun Q, van Dam RM, Franco OH, Manson JE, Willett WC, Ascherio A, Hu FB (2010). Bidirectional association between depression and type 2 diabetes mellitus in women. Archives of Internal Medicine 170, 1884 1891.

Parker AM, Sricharoenchai T, Raparla S, Schneck KW, Bienvenu OJ, Needham DM (2015). Posttraumatic stress disorder in critical illness survivors: a metaanalysis. Critical Care Medicine 43, 1121-1129.

Passos IC, Vasconcelos-Moreno MP, Costa LG, Kunz M, Brietzke E, Quevedo J, Salum G, Magalhaes PV, Kapczinski F, Kauer-Sant'Anna M (2015). Inflammatory markers in post-traumatic stress disorder: a systematic review, meta-analysis, and meta-regression. Lancet Psychiatry 2, 1002-1012.

Perkonigg A, Owashi T, Stein MB, Kirschbaum C, Wittchen HU (2009). Posttraumatic stress disorder and obesity: evidence for a risk association. American Journal of Preventive Medicine 36, 1-8.

Pitman RK, Rasmusson AM, Koenen KC, Shin LM, Orr SP, Gilbertson MW, Milad MR, Liberzon I (2012). Biological studies of post-traumatic stress disorder. Nature Reviews Neuroscience 13, 769-787.

Plantinga L, Bremner JD, Miller AH, Jones DP, Veledar E, Goldberg J, Vaccarino V (2013). Association between posttraumatic stress disorder and inflammation: a twin study. Brain, Behavior, and Immunity 30, 125-132.

Pole N, Neylan TC, Otte C, Henn-Hasse C, Metzler TJ, Marmar CR (2009). Prospective prediction of posttraumatic stress disorder symptoms using fear potentiated auditory startle responses. Biological Psychiatry 65, 235-240. 
Prins BP, Abbasi A, Wong A, Vaez A, Nolte I, Franceschini N, Stuart PE, Guterriez Achury J, Mistry V, Bradfield JP, Valdes AM, Bras J, Shatunov A, Lu C, Han B, Raychaudhuri S, Bevan S, Mayes MD, Tsoi LC, Evangelou E, Nair RP, Grant SF, Polychronakos C, Radstake TR, van Heel DA, Dunstan ML, Wood NW, Al-Chalabi A, Dehghan A, Hakonarson H, Markus HS, Elder JT, Knight J, Arking DE, Spector TD, Koeleman BP, van Duijn CM, Martin J, Morris AP, Weersma RK, Wijmenga C, Munroe PB, Perry JR, Pouget JG, Jamshidi Y, Snieder H, Alizadeh BZ (2016). Investigating the causal relationship of C-reactive protein with 32 complex somatic and psychiatric outcomes: a large-scale cross-consortium Mendelian randomization study. PLoS Medicine 13, e1001976.

Roberts AL, Agnew-Blais JC, Spiegelman D, Kubzansky LD, Mason SM, Galea S, Hu FB, Rich-Edwards JW, Koenen KC (2015). Posttraumatic stress disorder and incidence of type 2 diabetes mellitus in a sample of women: a 22-year longitudinal study. JAMA Psychiatry 72, 203-210.

Robins JM, Hernán MA, Brumback B (2000). Marginal structural models and causal inference in epidemiology. Epidemiology 11, 550-560.

Roy SS, Foraker RE, Girton RA, Mansfield AJ (2015). Posttraumatic stress disorder and incident heart failure among a community-based sample of US veterans. American Journal of Public Health 105, 757-763.

Rusiecki JA, Chen L, Srikantan V, Zhang L, Yan L, Polin ML, Baccarelli A (2012). DNA methylation in repetitive elements and post-traumatic stress disorder: a case-control study of US military service members. Epigenomics 4, 29-40.

Sadeh N, Miller MW, Wolf EJ, Harknes KL (2015). Negative emotionality and disconstraint influence PTSD symptom course via exposure to new major adverse life events. Journal of Anxiety Disorders 31, 20-27.

Santiago PN, Ursano RJ, Gray CL, Pynoos RS, Spiegel D, Lewis-Fernandez R, Friedman MJ, Fullerton CS (2013). A systematic review of PTSD prevalence and trajectories in DSM-5 defined trauma exposed populations: intentional and non-intentional traumatic events. PLOS ONE 8, e59236.

Schaefer JD, Caspi A, Belsky DW, Harrington H, Houts R, Israel S, Levine ME, Sugden K, Williams B, Poulton $R$, Moffit TE (2015). Early-life intelligence predicts midlife biological age. Journals of Gerontology Series B: Psychological Sciences and Social Sciences. Published online 26 May 2015. doi:10.1093/geronb/gbv035.

Scherrer JF, Chrusciel T, Zeringue A, Garfield LD, Hauptman PJ, Lustman PJ, Freedland KE, Carney RM, Bucholz KK, Owen R (2010). Anxiety disorders increase risk for incident myocardial infarction in depressed and nondepressed Veterans Administration patients. American Heart Journal 159, 772-779.

Schnurr PP, Spiro AI (1999). Combat disorder, posttraumatic stress disorder symptoms, and health behaviors as predictors of self-reported physical health in older veterans. Journal of Nervous and Mental Disease 187, 353-359.

Schnurr PP, Spiro AI, Vielhauer MJ, Findler MN, Hamblen JL (2002). Trauma in the lives of older men: findings from the Normative Aging Study. Journal of Clinical Geropsychology 8, 175-187.
Scott KM, McGee MA, Wells JE, Oakley Browne MA (2008). Obesity and mental disorders in the adult general population. Journal of Psychosomatic Research 64, 97-105.

Seckl JR (2007). Glucocorticoids, developmental 'programming' and the risk of affective dysfunction. Progress in Brain Research 167, 17-34.

Seckl JR, Meaney MJ (2006). Glucocorticoid "programming" and PTSD risk. Annals of New York Academy of Science 1071, 351-378.

Shah AJ, Lampert R, Goldberg J, Veledar E, Bremner JD, Vaccarino V (2013). Posttraumatic stress disorder and impaired autonomic modulation in male twins. Biological Psychiatry 73, 1103-1110.

Sledjeski EM, Speisman B, Dierker LC (2008). Does number of lifetime traumas explain the relationship between PTSD and chronic medical conditions? Answers from the National Comorbidity Survey-Replication (NCS-R). Journal of Behavioral Medicine 31, 341-349.

Smith AK, Conneely KN, Kilaru V, Mercer KB, Weiss TE, Bradley B, Tang Y, Gillespie CF, Cubells JF, Ressler KJ (2011). Differential immune system DNA methylation and cytokine regulation in post-traumatic stress disorder. American Journal of Medical Genetics Part B: Neuropsychiatric Genetics 156B, 700-708.

Smith GD, Ebrahim S (2003). 'Mendelian randomization': can genetic epidemiology contribute to understanding environmental determinants of disease? International Journal of Epidemiology 32, 1-22.

Spitzer C, Barnow S, Völzke H, Wallaschofski H, John U, Freyberger HJ, Löwe B, Grabe HJ (2010). Association of posttraumatic stress disorder with low-grade elevation of C-reactive protein: evidence from the general population. Journal of Psychiatric Research 44, 15-21.

Su S, Jimenez MP, Roberts CT, Loucks EB (2015). The role of adverse childhood experiences in cardiovascular disease risk: a review with emphasis on plausible mechanisms. Current Cardiology Reports 17, 88.

Suglia SF, Clark CJ, Boynton-Jarrett R, Kressin NR, Koenen KC (2014). Child maltreatment and hypertension in young adulthood. BMC Public Health 14, 1149.

Sumner JA, Kubzansky LD, Elkind MS, Roberts AL, Agnew-Blais J, Chen Q, Cerdá M, Rexrode KM, Rich-Edwards JW, Spiegelman D (2015). Trauma exposure and posttraumatic stress disorder symptoms predict onset of cardiovascular events in women. Circulation 132, 251-259.

Tchetgen Tchetgen EJ (2014). Identification and estimation of survivor average causal effects. Statistics in Medicine 33, 3601-3628.

Tchetgen Tchetgen EJ, Glymour MM, Shpitser I, Weuve J (2012). Rejoinder: to weight or not to weight?: On the relation between inverse-probability weighting and principal stratification for truncation by death. Epidemiology 23, 132-137.

Thayer JF, Brosschot JF (2005). Psychosomatics and psychopathology: looking up and down from the brain. Psychoneuroendocrinology 30, 1050-1058.

Tsigos C, Chrousos GP (2002). Hypothalamic-pituitaryadrenal axis, neuroendocrine factors and stress. Journal of Psychosomatic Research 53, 865-871. 
Vaccarino V, Goldberg J, Magruder KM, Forsberg CW, Friedman MJ, Litz BT, Heagerty PJ, Huang GD, Gleason TC, Smith NL (2014). Posttraumatic stress disorder and incidence of type-2 diabetes: a prospective twin study. Journal of Psychiatric Research 56, 158-164.

Vaccarino V, Goldberg J, Rooks C, Shah AJ, Veledar E, Faber TL, Votaw JR, Forsberg CW, Bremner JD (2013). Post-traumatic stress disorder and incidence of coronary heart disease: a twin study. Journal of the American College of Cardiology 62, 970-978.

van der Velden PG, Kleber RJ, Koenen KC (2008). Smoking predicts posttraumatic stress symptoms among rescue workers: a prospective study of ambulance personnel involved in the Enschede Fireworks Disaster. Drug and Alcohol Dependence 94, 267-271.

van Zuiden M, Geuze E, Willemen HL, Vermetten E, Maas M, Amarouchi K, Kavelaars A, Heijnen CJ (2012). Glucocorticoid receptor pathway components predict posttraumatic stress disorder symptom development: a prospective study. Biological Psychiatry 71, 309-316.

van Zuiden M, Geuze E, Willemen HL, Vermetten E, Maas M, Heijnen CJ, Kavelaars A (2011). Pre-existing high glucocorticoid receptor number predicting development of posttraumatic stress symptoms after military deployment. American Journal of Psychiatry 168, 89-96.

Vandenbroucke JP, Broadbent A, Pearce N (2016). Causality and causal inference in epidemiology: the need for a pluralistic approach. International Journal of Epidemiology. Published online 22 January 2016. doi: 10.1093/ije/dyv341.

Vin-Raviv N, Hillyer GC, Hershman DL, Galea S, Leoce N, Bovbjerg DH, Kushi LH, Kroenke C, Lamerato L, Ambrosone CB, Valdimorsdottir $\mathrm{H}$, Jandorf $\mathrm{L}$, Mandelblat JS, Tsai WY, Neugut AI (2013). Racial disparities in posttraumatic stress after diagnosis of localized breast cancer: the BQUAL study. Journal of the National Cancer Institute 105, 563-572.

von Känel R, Abbas CC, Schmid J-P, Saner H, Haeberli A, Stutz M, Begré S (2010). Momentary stress moderates procoagulant reactivity to a trauma-specific interview in patients with posttraumatic stress disorder caused by myocardial infarction. Journal of Psychiatric Research 44, 956-963.
Von Känel R, Hepp U, Buddeberg C, Keel M, Mica L, Aschbacher K, Schnyder U (2006). Altered blood coagulation in patients with posttraumatic stress disorder. Psychosomatic Medicine 68, 598-604.

von Känel R, Hepp U, Traber R, Kraemer B, Mica L, Keel M, Mausbach BT, Schnyder U (2008). Measures of endothelial dysfunction in plasma of patients with posttraumatic stress disorder. Psychiatry Research 158, 363-373.

Weathers F, Blake D, Schnurr P, Kaloupek D, Marx B, Keane T (2013). The Life Events Checklist for DSM-5 (LEC-5). National Center for PTSD: Washington, DC (www.ptsd.va.gov).

Weisskopf MG, Kioumourtzoglou MA, Roberts AL (2015). Air pollution and autism spectrum disorders: causal or confounded? Current Environmental Health Reports 2, 430-439.

Wentworth BA, Stein MB, Redwine LS, Xue Y, Taub PR, Clopton P, Nayak KR, Maisel AS (2013). Post-traumatic stress disorder: a fast track to premature cardiovascular disease? Cardiology in Review 21, 16-22.

Winning A, Glymour MM, McCormick MC, Gilsanz P, Kubzansky LD (2015). Psychological distress across the life course and cardiometabolic risk: findings from the 1958 British Birth Cohort Study. Journal of the American College of Cardiology 66, 1577-1586.

Wolf EJ, Bovin MJ, Green JD, Mitchell KS, Stoop TB, Barretto KM, Jackson CE, Lee LO, Fang SC, Trachtenberg F, Rosen RC, Keane TM, Marx BP (2016). Longitudinal associations between post-traumatic stress disorder and metabolic syndrome severity. Psychological Medicine 46, 2215-2226.

Yehuda R (2006). Advances in understanding neuroendocrine alterations in PTSD and their therapeutic implications. Annals of the New York Academy of Science 1071, 137-166.

Yehuda R, Flory J, Pratchett L, Buxbaum J, Ising M, Holsboer F (2010). Putative biological mechanisms for the association between early life adversity and the subsequent development of PTSD. Psychopharmacology 212, 405-417.

Zoellner LA, Pruitt LD, Farach FJ, Jun JJ (2014). Understanding heterogeneity in PTSD: fear, dysphoria, and distress. Depression and Anxiety 31, 97-106. 